\title{
STATUS MONITORING AND CONSERVATION ISSUES OF TEINOPALPUS IMPERIALIS HOPE (LEPIDOPTERA: PAPILIONIDAE), AN ENDANGERED BUTTERFLY OF NEPAL
}

\author{
BHAIYA KHANAL ${ }^{1} \otimes, K^{\prime}$ KESHB SHRESTHA ${ }^{1}$ AND MADAN KRISHNA SHRESTHA ${ }^{2}$
}

${ }^{1}$ Natural History Museum, Tribhuvan University, Swayambhu, Kathmandu, Nepal ${ }^{2}$ Pharping, Kathmandu, Nepal

baya2000@live.com

\section{ABSTRACT}

Teinopalpus imperialis an endangered swallowtail butterfly of high conservation value is encompassed into the Appendix II of CITES (Convention of International Trade of Endangered Species). This butterfly prefers its habitat at the altitudinal range of 2180 - $3000 \mathrm{~m}$ and emerges out for a brief period in summer months of May till July first week annually. This target species dwells in the broad leaved evergreen and mixed forest of Oaks (Quercus spp.).

This specific work made an extensive study of Teinopalpus imperialis with respect to its population status, associated habitats and prevailing threats in Phulchoki Mountain (Lalitpur District), Nagarjun -Shivapuri National Park (Kathmandu District) and Nagarkot Mountain (Bhaktapur District). This revealed out the occurrence of 21 individual populations of this butterfly in the Phulchoki Mountain and 8 individuals in the Nagarjun forest. Nagarkot of Bhaktapur district did not represent any of this species due to prevailing high impact on its habitat area.

Keywords: CITES appendix, Phulchoki, pupa, population, impact

\section{INTRODUCTION}

Teinopalpus imperialis (Hope,1843), an endangered swallowtail butterfly has a narrow distribution range confined to limited pockets of the country. The nominate race of this butterfly occurs in some specific areas of Kaski, Lalitpur, Kathmandu and Bhaktapur Districts with no records from rest of the country. Since its first record made by Ramsay in eighteenth century and Smith in 1989, no monitoring process was adopted to determine its existing population and conservation status. The Kaiser-I-Hind is confined to the thickly wooded districts at the altitude of 2000 to 3500 m in Nepal, north-eastern India, Bhutan, and China (Smith, 1989). Of the CITES listed species found in Nepal viz. Teinopalpus imperialis, Troides aeacus and $T$. helenus, the first one is said to carry high demand for the illegal dealers and traders.

This is a fast flying butterfly especially on tree-tops. Males are known to descend down to rest on ground vegetations. Male sucks moisture contains of the leaves and visits moist areas frequently. This butterfly prefers open space of the forested hills and mountain tops. Males are territorial and aggressive to other intruding males. This is a localized species found at the elevations of $2180 \mathrm{~m}$ to $3000 \mathrm{~m}$ in Nepal while in India its record has been made at $1820 \mathrm{~m}$ to $3000 \mathrm{~m}$ in the broad leaved evergreen forest mixed with conifers and often with oaks (Talbot, 1939).

The elevation of the Phulchoki Mountain ranges up from Godavari at $1400 \mathrm{~m}$ to the maximum 
elevation of $2735 \mathrm{~m}$. This vertical zonation represents forests of Schima wallichii and Castanopsis indica on the lower slope, while the upper part comprises Quercus lamillosa and $Q$. lanata mixed with Rhododendron arboreum, and the highest elevation represents $Q$. semicarpifolia with spreading bamboo species. This mountain shelters many interesting faunal components including endemic Turdoides nepalensis (Spiny Babbler) besides many other bird species (Fleming et al., 1976). Nagarjun-Shivapuri National Park has good representation of interesting components of the biodiversity. This park has interesting floral species like Spiraea micrantha, Arenaria glandulosa, Anemone vitifolia, Clematis buchanania, Ranunculus diffuses, Thalictrum foliolosum, Schisandra grandiflora, Berberis asiatica, Holboelia latifolia etc which are widely spread (DPR, 1973) in this part. Nagarkot of Bhaktapur district represents notable vegetations like Pinus roxburghii, Viburnum sps, Hypericum sps, Schima wallichii, Quercus glauca, Euphorbia sps, Berberis aristata, Prunus cerasoides etc.

\section{MATERIALS AND METHODS}

This study considered the months of mid May to July first week during which this butterfly is on wing in central Nepal. Frequency of this species was noted carefully without repetition. Field data like elevation, date, time and locality was recorded to accuracy into the data sheet. Literatures were also surveyed to obtain further information on its association to habitat vegetations (Igarashi, 1987; Talbot, 1939; Laithwaite, 1975). Eleven visits were made to the study sites in May to July first week. Smith (1989) and Khanal and Smith (1997) were consulted to confirm its species identification. The floral species collected in and around the habitats of the target species were identified at the Natural History Museum in Kathmandu besides consulting literatures by Polunin and Stainton (1984) and Stainton (1988). Plants collected at the three different study sites have been deposited at the Natural History Museum, Kathmandu.

\section{STUDY AREAS}

a. Phulchoki Mountain of Lalitpur District Phulchoki Mountain lies at $16 \mathrm{~km}$ southeast of Kathmandu city and stands at $27^{\circ} 58^{\prime} \mathrm{N}$ to $85^{\circ} 39^{\prime} \mathrm{E}$ and $27^{\circ} 83^{\prime} \mathrm{N}$ to $85^{\circ} 38^{\prime} \mathrm{E}$. This mountain comprises a mixture of limestone and low-grade metamorphic marble. Notable butterflies recorded in Phulchoki are Troides aeacus (Golden Birdwing), Achillides krishna (Krishna Peacock), Dilipa morgiana, Delias belladona (Hill Jezebel) and Teinopalpus imperialis (Kaiser E Hind).

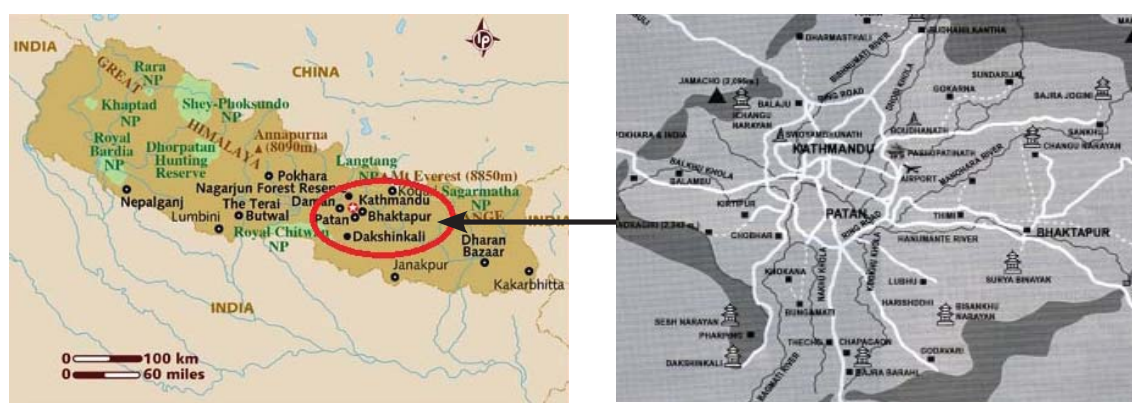




\section{b. Shivapuri-Nagarjun National Park of Kathmandu District.}

This place at $27^{\circ} 45^{\prime} \mathrm{N}$ and $85^{\circ} 15^{\prime} \mathrm{E}$ represents mixed broad leaved forest. Common butterflies found here are Metaporia agathon (Great Blackvein), Catopsilia pomana (Lemon Emigrant), Zemeros flegyas (Punchinello), Aglais cashmirensis (Tortoise Shell), Danaus aglea (Glassy Tiger), Pieris brassicae (Large Cabbage White), Papilio memnon (Great Mormon) etc.

\section{c. Nagarkot of Bhaktapur District}

The Nagarkot hill on its geographical stand of $27^{\circ} 65^{\prime} \mathrm{N}$ to $85^{\circ} 41^{\prime} \mathrm{E}$ lies at $2111 \mathrm{~m}$ of elevation from msl. Butterfly diversity noted here are mainly, Large Cabbage White (Pieris brassicae), Pale Clouded Yellow (Colias fieldii), Common Tortoise Shell (Aglais cashmirensis), Glassy Tiger (Danaus aglea), Common Tiger (Danaus chryssipus), Common Peacock (Achillides polyctor) etc.

\section{RESULTS}

This study in May to July of 2009 was specially designed to monitor the population and conservation status of Teinopalpus imperialis, a CITES listed (Appendix II) and endangered butterfly found in three adjoining districts of Kathmandu Valley. The current population data resulted from this study is provided below.

\section{Description of species}

Wing span: 90-120 mm. Forewing has a dark curved line and blackish indistinct band. Outer margin has white fringes. Hindwing contains dark discal line at distal side with golden yellow area. Sub-marginal lunules are greenish yellow, single yellow tipped tail in male. The size of female is little larger than the male. Forewing of female has grey bands. Hind wing with a large grey area. Presence of two tails, one is shorter at vein 6 and next longer at vein 4 .

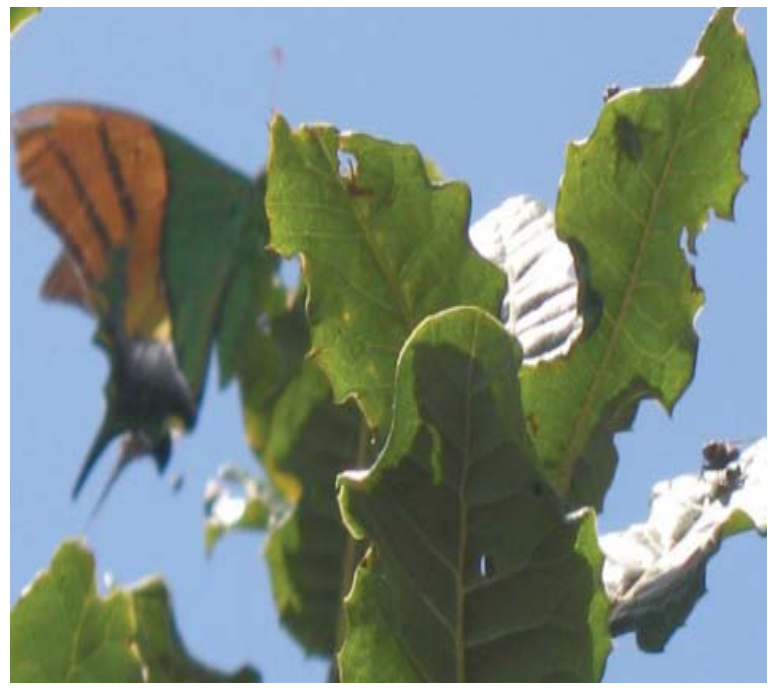

РНОTO 1.Teinopalpus imperialis on Quercus semicarpifolia Tree in Phulchoki Top. 


\section{Population Data}

TABLE 1. Population data of Teinopalpus imperialis in three places of Kathmandu valley

\begin{tabular}{|c|c|c|c|c|}
\hline Place & Altitude & $\begin{array}{c}\text { Total } \\
\text { Observation }\end{array}$ & Date & Time of Sightings \\
\hline \multirow[t]{2}{*}{ Phulchoki } & \multirow[t]{2}{*}{2700 to $2734 \mathrm{~m}$} & $\begin{array}{l}\text { May- } X \\
\text { June }=12 \\
\text { specimens }\end{array}$ & $\begin{array}{l}\text { May } 22,27, \text { June } \\
3,7,8,16,26 \\
27,29\end{array}$ & $9 \mathrm{AM}$ to $11.45 \mathrm{~A} . \mathrm{M}$ \\
\hline & & $\begin{array}{l}\text { July }=9 \\
\text { specimens }\end{array}$ & $\begin{array}{l}\text { July } 3,7,18 \\
24,28 .\end{array}$ & 9 AM to 12 Noon \\
\hline \multirow[t]{2}{*}{ Nagarjun } & \multirow[t]{2}{*}{$2300-2350 \mathrm{~m}$} & $\begin{array}{l}\text { May }=X \\
\text { June }=8 \\
\text { specimens }\end{array}$ & $\begin{array}{l}\text { May 24, June } 5 \text {, } \\
10,23,24,\end{array}$ & $\begin{array}{l}8.30 \mathrm{~A} . \mathrm{M} \text { to } 12.30 \\
\mathrm{PM}\end{array}$ \\
\hline & & $\begin{array}{l}\text { July }=4 \\
\text { specimens }\end{array}$ & July $5,21,14$ & \\
\hline Nagarkot & $2100-2190 \mathrm{~m}$ & $\begin{array}{l}\text { May }=X \\
\text { June }=X \\
\text { July }=X\end{array}$ & $\begin{array}{l}\text { May } 29, \text { June } 24 \\
\text { July } 10, \text { July } 16\end{array}$ & 9 A.M. to 2 P.M \\
\hline
\end{tabular}

\section{Population Pie Chart}

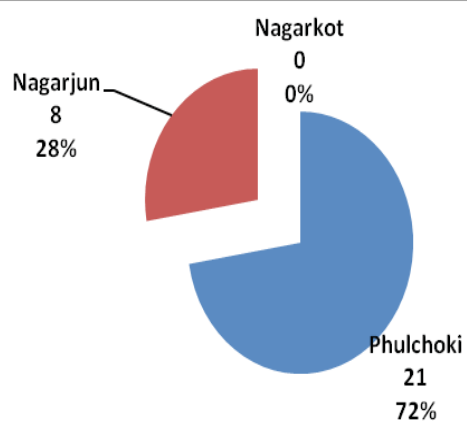

FIG.1. Percentage wise population of $T$. imperialis in study sites.

\section{DISCUSSION}

Significant study of Baruwa (2010) analyzed the effects of season, forest type, rainfall, year, altitude, and geographical position on the species assemblages of Papilionid butterflies in Assam of India. Results showed that the rainfall, forest type, and season accounted for most variance in the Papilionid abundance. Rainfall was strongly correlated with the abundance of some species. Diverse habitat preferences were found at the elevation of 1500-2000 m where 
85 species occurred. This elevation is influenced basically with the warm temperate climate sheltering butterflies of different habitat types. Cold climatic condition, scarce vegetation and few preferable habitats are the main causes of less diversity in higher elevation (Khanal et al., 2012). Seasonal environments (tropical and temperate regions) and climate gradients like temperature and precipitation play an important role in defining the differences in habitat preferences, biology, adult activity, reproductive strategy, and adaptive polyphenisms of butterflies (Brakefield \& Larson, 1984; McLeod ,1984).

The adult of this butterfly emerges out from its pupal case normally at the end of May when optimum temperature prevails. According to Igarashi (1987) this butterfly starts its appearance in late April in Darjeeling of India when the later becomes abundant in the latter half of May. It can also be seen in June but the population declines in July and becomes scarce in August. His study made in the Tiger Hill of Darjeeling revealed that this butterfly is a univolatine species. He mentioned that the Magnolia campbelli of the family Magnoliaceae is the food plant of this butterfly (Igarashi, 1987; Haribal, 1992). The next food plant as described in some literatures is a shrub called Daphne sps. (Talbot, 1939; Lathwaite, 1975; Gosh et al.,1983; Munroe, 1961; Okano, 1983; Collin \& Morris, 1985). Achillides krishna is a rare and endangered butterfly was also noted in the same habitat of Teinopalpus imperialis at $2734 \mathrm{~m}$ in the Phulchoki Mountain. Though not listed under the CITES Appendix, this species has been listed as Endangered under the IUCN Red List Status.

Though Teinopalpus imperialis was first described in 1843, its life history was not well documented until 1986 (Igarashi \& Fukuda, 2000). This swallowtail produces two broods per year (spring and late summer) (Igarashi, 2001). Females are much larger and rarer than males.

Considering its high trade value and rare status, Teinopalpus imperialis has been listed into the CITES Appendix II since 1987 (Federal Register, 2004). According to IUCN, nearly 14\% of the total species of this family (78 species) is being threatened or the species community is on severely declining stage. Among 46 species that need to be protected (listed in appendix I and II of CITES), Vietnam has 4 species, namely Teinopalpus aureus, Teinopalpus imperialis, Troides helena and Troides aeacus (Lien, 2011). The accelerating rate of habitat loss has altered the status of one hundred and fourty two species of Nepalese butterflies into the threat category (NRDB, 1995).

The Kaiser-I-Hind swallowtail does not represent a monotypic genus. The current threats of habitat destruction and illegal collections are moderate to low in magnitude due to its wide distribution in some countries, but imminent due to ongoing habitat destruction, high market value for specimens, and inadequate domestic protections for the species or its habitat (Federal Register, 2009). It also states that its current status is still not known in Bhutan, India, Laos, Myanmar and Nepal (before initiation to this study).

\section{Conservation Issues}

Considering its illegal trade and high conservation value this butterfly is protected by the respective Conservation Acts in different countries. In Nepal, this species is protected by Appendix II of CITES and Threatened Category of the National Red Data Book (1995). The Indian Wildlife Act of 1972 has listed this butterfly under the Schedule II (Collins \& Morris, 
1985). This swallowtail is listed under the Wildlife Reservation and Protection Act of 1992 in Thailand, which makes it illegal to collect (whether wild or dead) or to have the species in one's possession (Thai Government, 1992). According to Lien (2012), this species is very rare with scattered small populations in high altitude areas of Vietnam where natural forests are disturbed. Destruction of natural forest and over-collection has threatened this butterfly in this country. According to him this butterfly carry high conservation value in Vietnam.

Impact factors on the habitat of Teinopalpus imperialis in Kathmandu Valley:

- Phulchoki Mountain Top: Most of the trees are cut down except few trees of Quercus semicarpifolia in its habitat area. During this study the species were observed resting on these trees.

- Nagarjun Forest: This is the next potential area for this butterfly. The habitat at Nagarjun top or Jhama Cho $(2130 \mathrm{~m})$ is highly disturbed with hanging religious flags; these are installed massively upon the temple area with no free space for the movement to this butterfly. Majority of the trees are cut down except few trees of Castanopsis tribuloides in which Teinopalpus usually settled.

- Nagarkot: No Teinopalpus imperialis was seen at Nagarkot though occurred here a decade back (Khanal \& Smith, 1997). The habitat for this species is heavily pressurized with human activities, constructions and deforestation.

- Haphazard collections of fodders and fiber plants are causing heavy impact on the habitat of this butterfly.

- Forest fire in Phulchoki caused an extreme loss of its habitat area in 2009. Quercus semicarpifolia also suffered with this fire.

- Different bamboo species are spreading around the mountain area which also has depressed the population of the relevant plant species of the target butterfly.

\section{ACKNOWLEDGEMENTS}

We would like to express our sincere thanks to WWF-Nepal for the generous support to this work. Mr. Diwakar Chapagain, the senior official of WWF-Nepal is specially acknowledged for his valuable and timely suggestions. CEENED, a conservation based non-governmental organization in Kathmandu is appreciated for its cooperative affiliation to this work. Lastly, we appreciate the help of Mr. Kumar Lama and Deepak Tamang of Godavari during field visits.

\section{REFERENCES}

BARUWA, K K; SLOWIK, J; BOBO, K S; MUEHLENBERG, M (2010) Correlations of rainfall and forest type with Papilionid assemblages in Assam in northeast India. Psyche 2010, Article ID 560396:10.

BRAKEFIELD, P M; LARSEN T B (1984) The evolutionary significance of dry and wet season forms in some tropical butterflies. Biological Journal of the Linnean Society 22(1):1-12. 
COLLINS, M N; MORRIS, M G (1985) Threatened swallowtail butterflies of the world. IUCN, Gland, Switzerland; 200-202 pp.

DPR, (1973) Flora of Nagarjun. Bulletin of Department of Medicinal Plants (No.4). Ministry of Forest, Nepal Government, Kathmandu, Nepal.

FLEMING, R L., SR., FLEMING R L, JR.; BANGDEL, L S (1976) Birds of Nepal. FLEMING, R L SR., Box 229, Kathmandu, Nepal; 337 pp.

FEDERAL REGISTER, (2008). Endangered and threatened wildlife and plants: Annual notice of findings on resubmitted petitions for foreign species. US Fish and Wildlife Service, Department of Interior, July 29, United States 73(146): 44095-44096.

FEDERAL REGISTER, (2009). Endangered and threatened wildlife and plants: Annual notice of findings on resubmitted petitions for foreign species: Annual description of progress of listing actions. US Fish and Wildlife Service, Department of Interior, August 12, United States; 74(154): 40540-40560.

GHOSH, S K; MANDAL, D K (1983) Review of Kaiser-I-Hind butterfly, Teinopalpus imperialis Hope. Unpublished manuscript: 3.

HARIBAL, M 1992. The butterflies of Sikkim himalaya. Sikkim Nature Conservation Foundation, Gangtok Sikkim, India; 207 pp.

HOPE, F W (1843). Trans. Linn. Soc. Lond 19(2): 131.

IGARASHI, S; FUKUDA, H (2000) The life histories of Asian butterflies, Vol. II, Tokai University Press, Japan; $427 \mathrm{pp}$.

IGARASHI, S (1987) On the life history of Teinopapus imperialis Hope in northern India and its phylogenetic position in the Papilionidae. Tyo to Ga 38(3): 115-151.

IGARASHI, S (2001) Life history of Teinopalpus aureus in Vietnam in comparison with that of T. imperialis: Butterflies. No. 30 (December. 10, 2001), The Butterfly Society of Japan; pp. 4-24.

KHANAL, B; CHALISE M K; SOLANKI,G S (2013) Threatened butterflies of central Nepal. Journal of Threatened Taxa 5(11): 4612-4615.

KHANAL, B; CHALISE M K; SOLANKI,G S (2012) Diversity of butterflies with respect to altitudinal rise at various pockets of the Langtang National Park, central Nepal. International Multidisciplinary Research Journal 2(2): 41-48. Available Online: http://irjs.info/.

KHANAL, B; SMITH, C (1997) Butterflies of Kathmandu valley. Tecpress Service, Bangkok, Thailand: 3.

LAITHWAITE, E; WATSON, A; WHALLEY, P E S (1975) The Dictionary of butterflies and moths in colour. George Rainbird Limited, UK; 145 pp.

LIEN, H (2011) Precious butterfly Teinopalpus aureus in Vietnam. Vietnam Academy of Science and Technology, Vietnam.

LIEN, V V (2012) Two butterflies species of rare and specious genus Teinopalpus Hope, 1843 in Vietnam 34(3): 323-327.

McLEOD, L (1984) Seasonal Polyphenism in African Precis butterflies, In Vane-Wright, R I;. ACKERY, P R (eds) The biology of butterflies. Symposium of the Royal Entomological Society, , Academic Press, London, UK; pp. 313-315.

MUNROE, E (1961) The classification of the Papilionidae (Lepidoptera). Canadian Entomologist Supplement 17: $1-51$. 
NEW, T R (1991) Swallowtail butterflies: An action plan for their conservation. IUCN, Gland, Switzerland; $288 \mathrm{pp}$.

NRDB, (1995) Red data book of the fauna of Nepal. Biodiversity Profile Project, Technical Report No.4, Department of National Parks and Wild life Conservation, Nepal Government, Kathmandu, Nepal;150 pp. OKANO, K (1983) Some ecological notes on Teinopalpus. Tokurana 5:94-1100 (in Japanese).

Polunin, O; Satinton, A (1984) Flowers of the Himalaya. Oxford University Press. UK; 580 pp.

SMITH, C (1989) Butterflies of Nepal. Tecpress Service, Bangkok, Thailand; 38 pp.

Stainton, A. (1988). Flowers of the Himalaya: A Supplement. Oxford University Press, Oxford India Paperbacks, New Delhi.

TALBOT, G (1939) The Fauna of British India, including Ceylon and Burma. Butterflies (Papilionidae \& Pieridae), Vol. I, Taylor and Francis, London, UK; pp. 246-249.

THAI GOVERNMENT (1992). Act for the conservation and protection of wildlife B.E. 2535,

FAL No. 43, 1993, Thailand; 265-267 